\title{
Extending the Kenney-Lau method to dam core soils of glacial till
}

Hans Rönnqvist Lic Eng

PhD student, Department of Civil, Environmental and Natural Resources

Engineering, Luleå University of Technology, Luleå, Sweden
Peter Viklander PhD

Adjunct Professor, Department of Civil, Environmental and Natural Resources Engineering, Luleå University of Technology, Luleå, Sweden

The Kenney-Lau method, which is used to assess the internal stability of granular soils, is stretched in engineering practice to include soils with fines. This strays beyond the method's intended range and may introduce potential uncertainty in terms of validity. Herein, results are presented from the assessment of grain size curves from core construction data belonging to a large number of existing dams with core material composed of widely graded glacial till soils. Some have experienced internal erosion events, and others have not, and based on the benchmark of historic performance data of these dams, the validity of the Kenney-Lau method in terms of glacial tills is investigated. Only dams in the same filter coarseness range are studied in order to reduce the influence of the filter. By contrasting dams with documented internal erosion history against the application results of the method, it indicates that the Kenney-Lau method can be extended with caution to include glacial till cores if within the proposed fines content and finer fraction ranges.

\section{Notation \\ $D_{15} \quad$ grain size $(\mathrm{mm})$ at $15 \%$ passing weight of the filter \\ $d_{85} \quad$ grain size $(\mathrm{mm})$ at $85 \%$ passing weight of the core/base \\ $d_{95} \quad$ grain size $(\mathrm{mm})$ at $95 \%$ passing weight of the core/base \\ $D_{\max } \quad$ maximum particle size (mm) \\ $F \quad$ passing weight of material at particle size $d(\%)$ \\ $H / F_{\text {min }} \quad$ Kenney and Lau stability index (lowest $H / F$ value within the evaluation range of $0 \%-20 \%$ passing weight for widely graded materials) \\ $H$ mass fraction of particle sizes between $d$ and $4 d(\%)$}

\section{Introduction}

Dams impound water in reservoirs for various purposes (e.g. energy generation, irrigation etc.). Embankment dams maintain the reservoir by an impervious core. The core is protected from erosion by filters. If a filter is ineffective, fine-grained particles can be carried by seepage, causing internal erosion of the core. The International Commission on Large Dams (ICOLD, 2013) recognises four mechanisms of initiation, that is, from concentrated leaks, backward erosion, contact erosion and suffusion. Suffusion erodes free-moving fines and may cause a property change in a soil, potentially making it less suitable as hydraulic barriers in embankment dams. For an internally unstable soil, there is an imbalance in the gradation between the coarser and finer fraction, causing shortage of fines and thus underfilled voids. This creates highly stressed particle contacts in the coarser fraction and loose erodible fine-grained particles in the soil's finer fraction.

In terms of dams comprising cores of broadly graded soils (i.e. glacial tills), the symptoms of late-stage internal erosion are typically sinkholes and settlements on the crest, seepage increase and cloudy seepage (Rönnqvist, 2009). Statistically, these core types have higher frequency of internal erosion incidents than dams with other types of core soils (Foster et al., 2000; Nilsson et al., 1999). Sherard (1979) attributed this to properties typical for widely graded glacial soil (e.g. internal instability). Although Wan and Fell (2004) proposed an approach to evaluate the internal instability of fine-rich soils, interestingly, considering its propensity for internal erosion, there is no available method specifically targeting glacial tills. However, a popular approach to assess the internal stability of soils is through the method of Kenney and Lau $(1985,1986)$, which is a criterion intended for the evaluation of granular filter materials based on laboratory results from seepage tests on cohesionless sands and gravels with particles up to $100 \mathrm{~mm}$. Their method evaluates the slope of the grain size curve, and in engineering practice, it is often stretched beyond its intended range (to include soils with fines), which may introduce potential uncertainty in terms of validity. However, Li and Fannin (2008) elaborated on the Kenney-Lau method, and they found that adapting it to include the Kezdi (1979) criterion may result in a less conservative evaluation; furthermore, their experimental observations indicate that with this adaptation it may indeed apply to soils with a fraction of non-plastic silt (Moffat and Fannin, 2011; Moffat et al., 2011).

Herein, the Kenney-Lau method and the Li-Fannin adaptation are applied on the grain size curves of a large number of existing dams with the objective to evaluate the internal stability of glacial till core soils. Considering that these cores indeed comprise fines, some with considerable amount, it potentially exceeds these methods' original scope. However, using the dams' historic performance data in terms of internal erosion as benchmark, the validity and potential evaluation range on glacial tills are investigated by contrasting the internal erosion performance data of dams against the application 
results of the methods. Recognising that the filters in dams are of utmost importance for the progression of internal erosion, only dams placing in the same filter coarseness range are incorporated in the comparative analysis in an attempt to minimise the influence of the filter, thus enhancing the influence of core soils.

\section{Internal instability and soils with fines}

A matrix-supported soil with no coarse grain contact is not susceptible to suffusion. Hence, for a soil to be internally unstable and subject to suffusion, it needs to have a finer fraction less than the available void space in the coarse fraction. This finer fraction is determined from the gradation curve's point of inflection, where there is a change in slope from the coarse fraction's initial slope (ICOLD, 2013). Opinions differ on this threshold finer fraction in the literature, that is, how large the maximum possible fraction of erodible particles in internally unstable soils can be, but Wan and Fell $(2004,2007)$ conclude that it theoretically can be as high as $40 \%$; however, for broadly graded test soils, their tests indicate between 22\% and 33\%. Skempton and Brogan (1994) estimated it to be $35 \%$, whereas Kenney and Lau (1985) estimated it to be only $20 \%$ for compacted widely graded materials from back-calculating the lost fraction of their tested unstable soils. A reasonable synthesis is that a soil is probably not susceptible to suffusion unless the finer fraction is less than about $25 \%$ to $35 \%$.

In terms of glacial tills and internal stability, not much published data are available. However, with seepage tests at a gradient of 10, Lafleur and Nguyen (2007) found that cohesionless broadly graded glacial tills with fines content of up to $12 \%$ (with $D_{\max }$ of $38 \mathrm{~mm}$ ) were susceptible to suffusion, but tills with higher content of fines were not. Wan (2005) found while subjecting it to a constant gradient of 8 that a glacial till with $20 \%$ fines (with $D_{\max }$ of $4.75 \mathrm{~mm}$ ) is not susceptible to suffusion. Nevertheless, Sherard and Dunnigan (1989) found in their no-erosion-filter tests that base materials with fines of up to $20 \%$ (with $D_{\max }$ of $4.75 \mathrm{~mm}$ ) behaved as friction materials (i.e. sand particles in contact), and Moffat and Fannin (2011) and Moffat et al. (2011) observed suffusive characteristics in a glacial soil with non-plastic fines up to $30 \%$ (with $D_{\max }$ of $20 \mathrm{~mm}$ ). Furthermore, from seepage tests, Lilja et al. (1998) reported internal instability in glacial tills with fines between $25 \%$ and $35 \%$ (with $D_{\max }$ of $30 \mathrm{~mm}$ ).

\section{The Kenney-Lau method and the Li-Fannin adaptation}

The Kenney and Lau $(1985,1986)$ method evaluates the potential for grading instability in soils from the material's grain size curve. The limiting-shape curve $H=1 \cdot 0 F$ present the boundary between internal stability and instability, where $H$ is the mass fraction of particle sizes between $d$ and $4 d$, and $F$ is the passing weight at particle size $d$ (Figure 1). A deficiency in the number of particles of a certain fraction (between $d$ and $4 d$ ) will potentially allow the erosion of particles more fine-grained than $d$; thus, an internally unstable material has $H<F$ (Kenney and Lau, 1985). Kenney and Lau (1985) showed that the evaluation range for widely graded materials is passing weight $0-20 \%$ (Figure 2). Li and Fannin (2008) proposed to extend the Kenney-Lau method to include the Kezdi (1979) criterion (Figure 2). The Kezdi (1979) method involves splitting the gradation curve into a fine and coarse component against a limiting criterion (i.e. $D_{15} / d_{85}=4$ ) that must be satisfied in order to be internally stable (Figure 1). The methods have similarities as both examine the slope of the grading curve over a certain length; as reported by Li and Fannin (2008), the Kezdi criterion is incremental over the percentage that is finer by mass, whereas the Kenney and Lau criterion is incremental over the grain size. Figure 2 describes

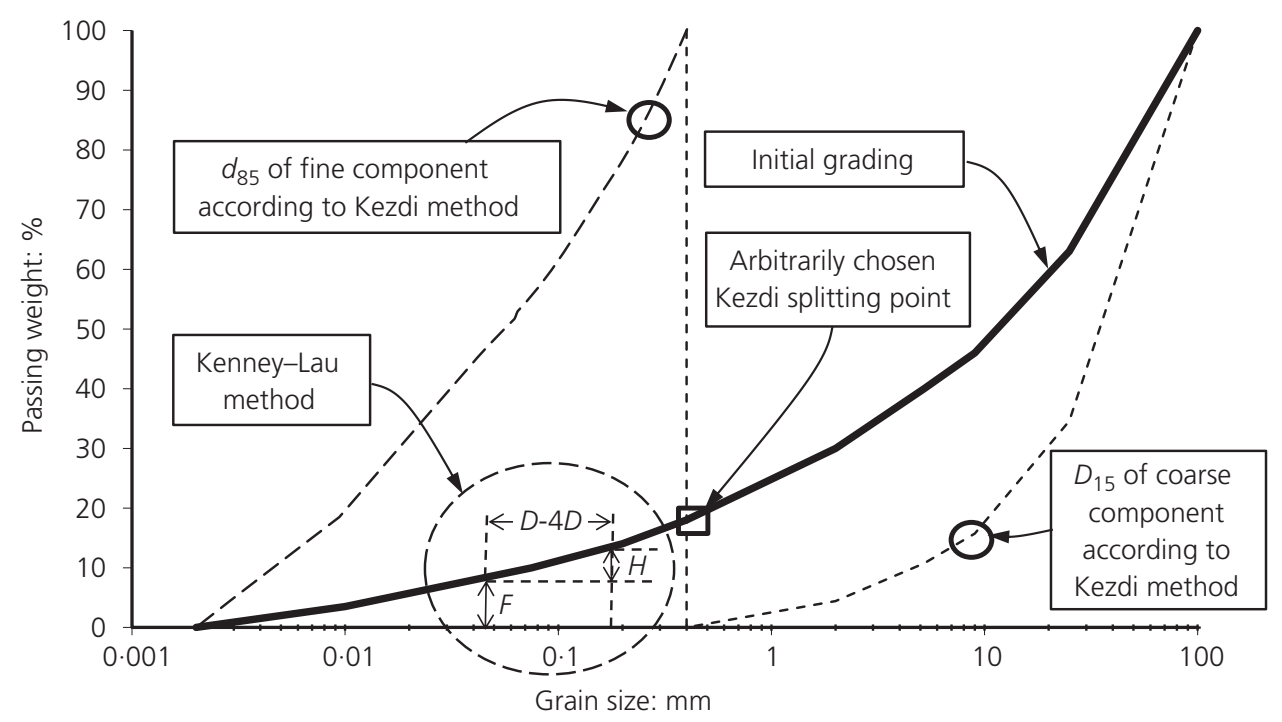

Figure 1. Schematic of the Kenney and Lau $(1985,1986)$ method and the Kezdi (1979) method 


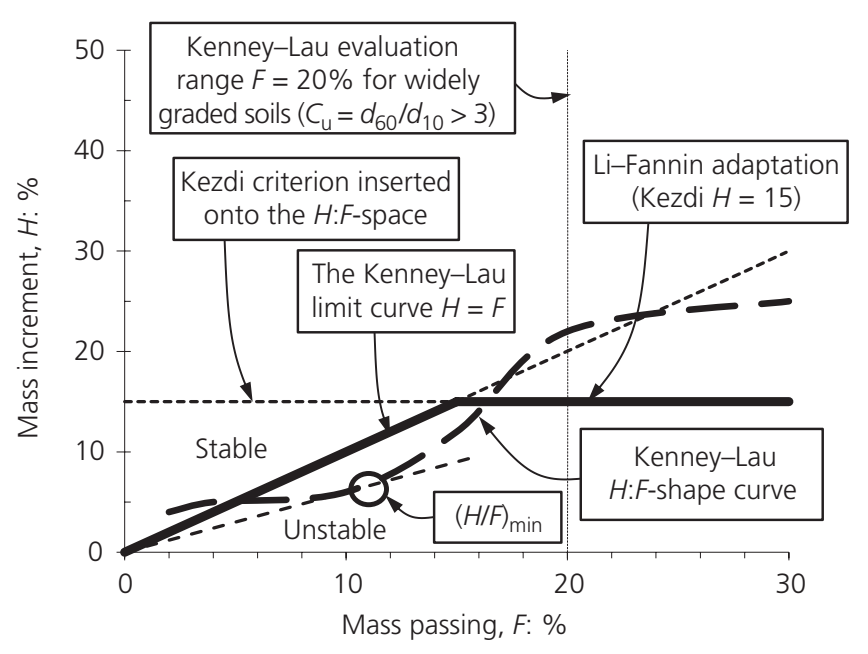

Figure 2. Application descriptions of the Kenney and Lau (1985, 1986) method and the Li and Fannin (2008) adaptation

the application of the Kenney-Lau method and the Li-Fannin adaptation for an example gradation, and furthermore, it shows how to generate the stability index $(H / F)_{\min }$ from the $H: F$-shape curve.

\section{Database of existing dams with cores of glacial till}

In Rönnqvist (2010), a database of existing embankment dams with impervious core material composed of glacial till belonging to Sherard and Dunnigan (1989)'s soil group 2 base soils (i.e. base soils having $40 \%$ to $85 \%$ finer than no. 200 sieve $(0.075 \mathrm{~mm})$ when regraded on the $4.75 \mathrm{~mm}$ sieve) was compiled. These core soils comprise granular, cohesionless glacial till with low to nil clay content and non-plastic or low plasticity fines. With source data from $(i)$ the dam owner's archives and (ii) case studies from the literature (mainly international dams), the performance history of the dams was studied with the objective to identify dams that have experienced internal erosion to separate these from dams that have serviced well since commissioning. The set of dams, when categorised according to the scheme given in Table 1, comprises 104 glacial till core dams in total; however, from this set, there are 74 dams with complete core data sufficient for evaluation, and these are studied hereon after. 23 of the dams have experienced internal erosion with field evidence of reported sinkholes (herein named category 1 dams), and these category 1 dams are given in detail in Table 3. Furthermore, in the following figures, these dams are traceable for continuity (denoted by uppercase letters in Table 3 ). The category 3 dams have operated without any signs of internal erosion, and the category 2 dams have had some observations of possible distress, but an obvious relation to internal erosion is not clear (Table 1); hence, internal erosion-free dams are hereon after named 'category 2-3 dams'. In Figure 3, the glacial till cores are described by the content of fines (for the full sample or reported maximum particle size - that is, no regrading of the original curve)

\begin{tabular}{|c|c|c|}
\hline Category & Definition & No. of dams \\
\hline 1 & $\begin{array}{l}\text { Category } 1 \text { dams - dams } \\
\text { with a probable occurrence } \\
\text { of internal erosion (the dam } \\
\text { has had documented internal } \\
\text { erosion). The internal erosion } \\
\text { incident has been published } \\
\text { by experts in case studies. } \\
\text { Source data and description } \\
\text { of these dams are given in } \\
\text { Table } 3 .\end{array}$ & 23 \\
\hline \multirow[t]{2}{*}{$2-3$} & $\begin{array}{l}\text { Category } 2 \text { dams - dams } \\
\text { where observations may } \\
\text { indicate signs of internal } \\
\text { erosion (presence of internal } \\
\text { erosion is not clear, until } \\
\text { proven otherwise; signs are } \\
\text { considered unrelated to } \\
\text { internal erosion). }\end{array}$ & 10 \\
\hline & $\begin{array}{l}\text { Category } 3 \text { dams - dams } \\
\text { with no observations to } \\
\text { indicate internal erosion } \\
\text { (fully functional dams with } \\
\text { no sinkholes or settlements } \\
\text { and no leakage with eroded } \\
\text { material throughout the life- } \\
\text { time of the dam to date). }\end{array}$ & 71 \\
\hline
\end{tabular}

Table 1. Dam categories with regards to history of internal erosion and number of dams

and in Figure 4 by finer fraction, with category 1 dams identifiable with denotation (as given in Table 3). The grain size curves of category 1 dam cores are given in Figure 5, which indicates the typical broad gradation of glacial tills as it ranges from coarse grained and low on fines (less than 5\%) to relatively fine grained with fines exceeding $50 \%$. The clay content is generally low $(5 \%$ and less), as given in Figure 5.

\section{Rationale for choosing data points}

All available representative core grain size curves have been compiled to create a representative soil envelope (Figure 6). Only as-built gradings are included. This envelope, from the fine limit, intermediate gradings to the coarse limit, is then evaluated for each dam. The conservative approach has been taken such that if one representative grading in the envelope is unstable then the core is considered unstable. The rationale for choosing which grain size curve to consider has been to identify the most vulnerable grain size curve from the envelope with respect to the Kenney-Lau method and the Li-Fannin adaptation, which then provide the most vulnerable data point presented in the following figures. Naturally, 
Extending the Kenney-Lau method to

dam core soils of glacial till

Rönnqvist and Viklander

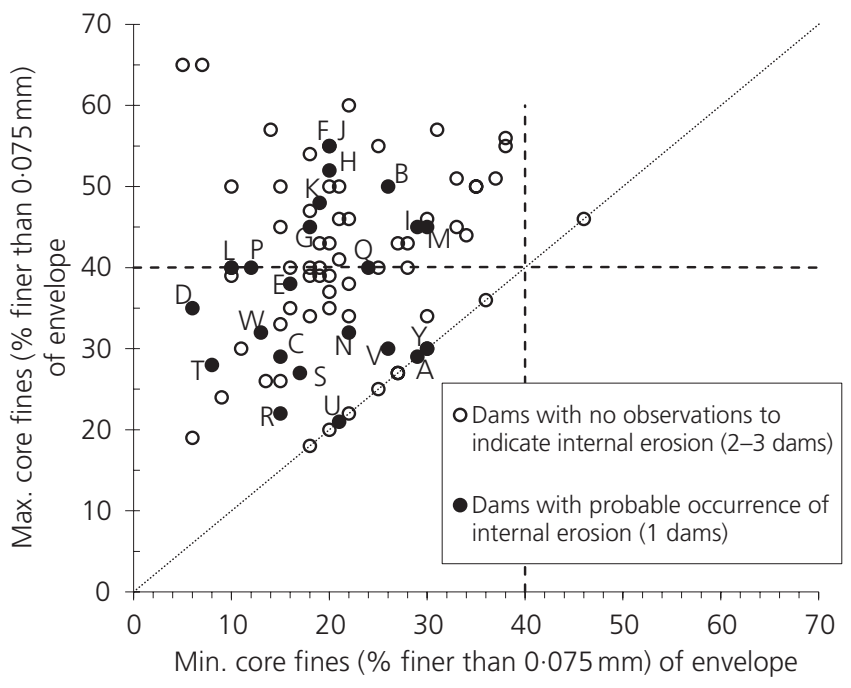

Figure 3. Core fines content and performance history of internal erosion (84 dams in total including 23 category 1 dams), based on the shape of original grain size curves that have not been regraded

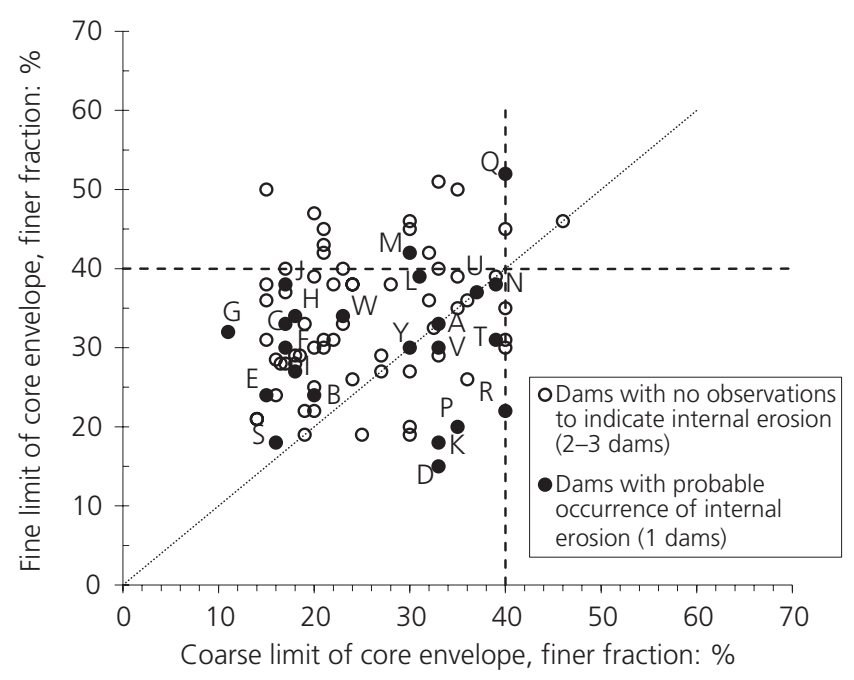

Figure 4. Core finer fraction and performance history of internal erosion (84 dams in total including 23 category 1 dams), based on the shape of original grain size curves that have not been regraded

when dealing with existing dams, the availability of data varies from case to case, and for some dams included in the study, only the outer limits (Figure 6) of the envelope have been available for evaluation.

\section{Reducing the influence of filter coarseness}

Although the erodability of the core soil is significant in the initiation of internal erosion and may also to some extent influence its progression (i.e. through self-filtering), the determining factor whether an initiated internal erosion process progresses or arrests is dependent on the effectiveness of the filter in protecting the core from eroding. Herein, the applicability of the Kenney-Lau method on core soils of glacial till is investigated by way of comparing application results against the historic performance of the dams. However, recognising the importance of the filter on the internal erosion progression (thus leading to signs of internal erosion on the dams), this back-tracking of an internal erosion incident to the internal stability of the core soil is delicate. It requires that the influence of the filter on the internal erosion process is reduced as much as possible. One possible way to achieve this is to perform the analysis on dams with similar filter coarseness (filter $D_{15}$ ), thus disregarding dams that fall outside this filter range, and by doing that a potential subordinate cause (e.g. core internal instability) that may co-influence the internal erosion progression is elevated.

Foster and Fell (2001) define 'base soil groups' (depending on the fines content of the base) and the corresponding filter required for there to be no erosion of the base soil. This is an elaboration of the soil groups proposed by Sherard and Dunnigan (1989), and Foster and Fell (2001) modified the original 40\% fines content subdivision of soil group ' 2 ' and ' 4 ' to instead be $35 \%$ (and thus renaming these '2A' and '4A'). Furthermore, Foster and Fell (2001) proposed boundaries for 'excessive erosion' and 'continuing erosion' for these base soil groups. The 'some erosion' range is found between the 'no erosion' boundary and the excessive counterpart. Figure 7 shows the adjusted grain size curves to $D_{\max }$ of $4.75 \mathrm{~mm}$ (which is in accordance with the proper procedure), and this indicates that the core soils in general belong to group $2 \mathrm{~A}$ ( $35 \%-85 \%$ fines). On the other hand, the coarse limit of the envelopes suggests group $4 \mathrm{~A}(15 \%-35 \%$ fines). This means that the 'some erosion' and 'excessive erosion' range as defined by Foster and Fell (2001) can vary for the dams (depending on soil group), but in general, the soil group 4A filter range is less strict than its counterpart in group 2A. In Figure 8, the core stability index $\left(H / F_{\min }\right)$, generated according to Kenney and Lau $(1985,1986)$, is plotted against the filter $D 15$ of the dams in the study. Figure 8 also shows the filter ranges as defined by Foster and Fell (2001), that is, 'no erosion,' 'some erosion,' 'excessive erosion' and 'continuing erosion.' As can be seen, although some dams would categorise as base soil group 4A, the 'excessive erosion' filter boundary roughly intersects the group 2A boundary, and simplified, this occurs at approximately filter $D_{15}$ of $6 \mathrm{~mm}$ (Figure 8). However, this is not an exact boundary but would instead generate a range since it depends on the composition of the core soil that varies from dam to dam, but this range exists around $6 \mathrm{~mm}$. Similarly, the 'continuing erosion' filter boundary (filter $D_{15} \geq 9 d_{95}$ ) is approximately $27 \mathrm{~mm}$ (Figure 8 ). The 'no erosion' boundary for filters to group $4 \mathrm{~A}$ base soils is normally permitted coarser than that of group 2A (i.e. $D_{15}$ of $0.7 \mathrm{~mm}$ ), but herein the no-erosion limit of Sherard and Dunnigan (1989) (i.e. $D_{15}=0.7 \mathrm{~mm}$ ) is used universally because they regarded glacial till base soil as belonging to soil group 2. Combining these show that the 'some erosion' range (i.e. $0 \cdot 7<D_{15}<6 \mathrm{~mm}$ ) comprises 44 dams in total (Figure 8), thus in the same filter coarseness range that minimises the filter influence and makes a population of dams appropriate for comparative analysis in terms of the core soil. 


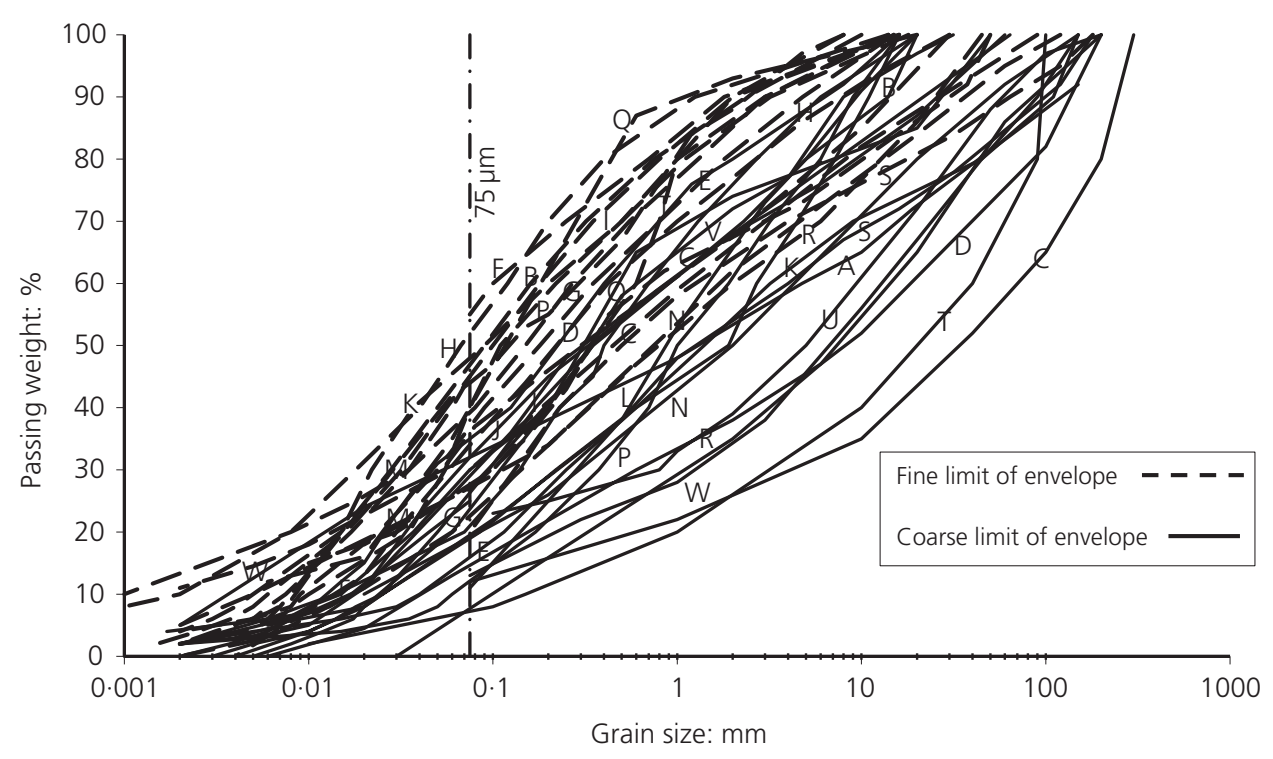

Figure 5. Core envelopes of 23 category 1 dams comprising original grain size curves (compare with Table 3 for dam data)

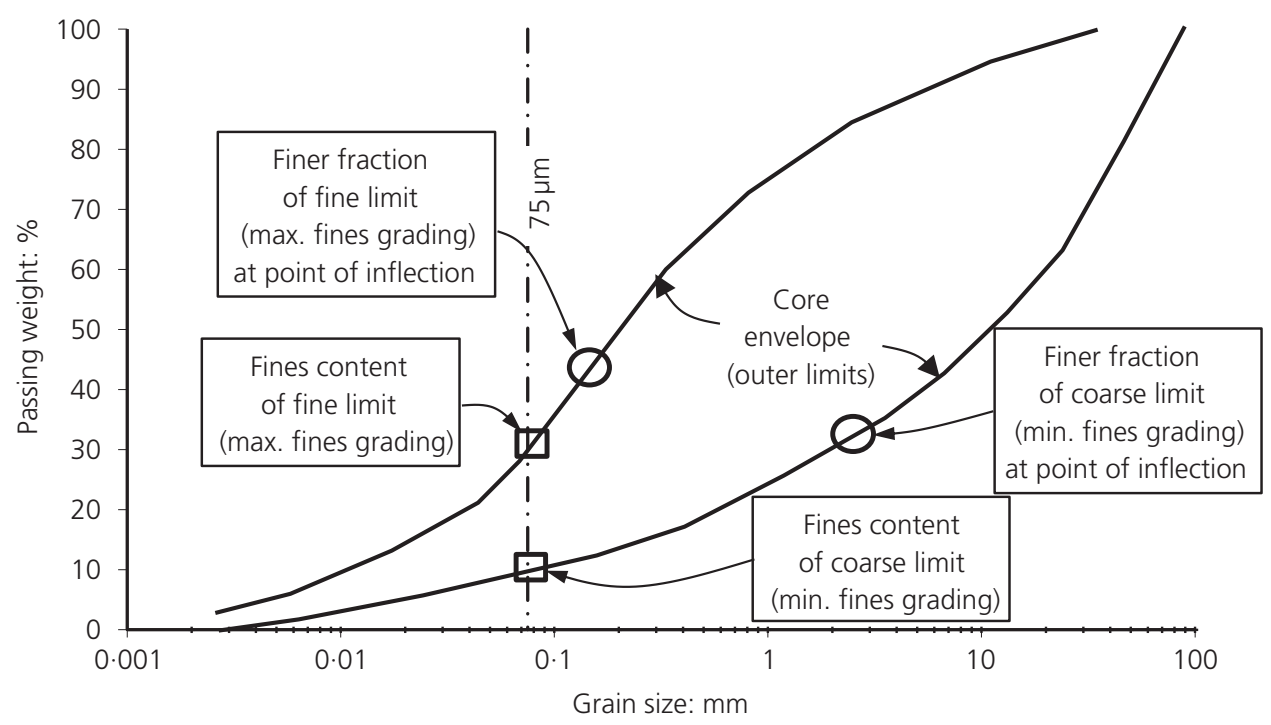

Figure 6. Schematic diagram showing how to determine fine content and finer fraction from the core envelope

\section{Evaluating core soils with fines using the Kenney-Lau method}

Theoretically, the majority of cores are susceptible to suffusion, thus relevant for internal stability evaluation as these have less than $35 \%$ finer fraction on the coarse limit of the envelope (Figure 4 ). According to previously stated methodology, only dams with filter coarseness in the same range are studied (i.e. 'some erosion' range in Figure 8). Figure 9 shows the Kenney-Lau application plots for these 44 dams with the Li-Fannin adaptation superimposed (i.e. Kezdi criterion $H=15 \%$ ). Fifteen of the dams are category 1 dams.
With the influence of the filter reduced, a correlation between dams with previous internal erosion incidents and core instability may suggest that the Kenney-Lau method has merit, that is, that the internal erosion process (leading to an incident) connects to the core instability, which is predicted by the method.

\section{Results from evaluation of data that is unscreened}

With no regard to the content of fines or the finer fraction of the cores of the 44 dams in the 'some erosion' range, there is relatively poor correlation between the core soils' stability index $\left(H / F_{\min }\right)$ and 
Extending the Kenney-Lau method to

dam core soils of glacial till

Rönnqvist and Viklander

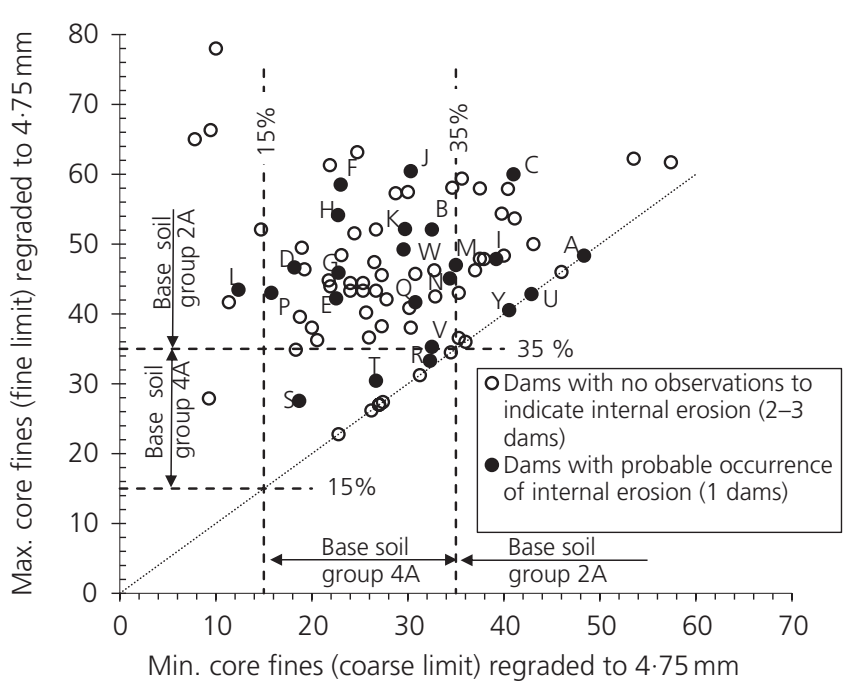

Figure 7. Core fines content when regraded on the $4 \cdot 75-\mathrm{mm}$ sieve and boundaries for base soil groups $2 \mathrm{~A}$ and $4 \mathrm{~A}$ as proposed by Foster and Fell (2001) (84 dams in total including 23 category 1 dams)

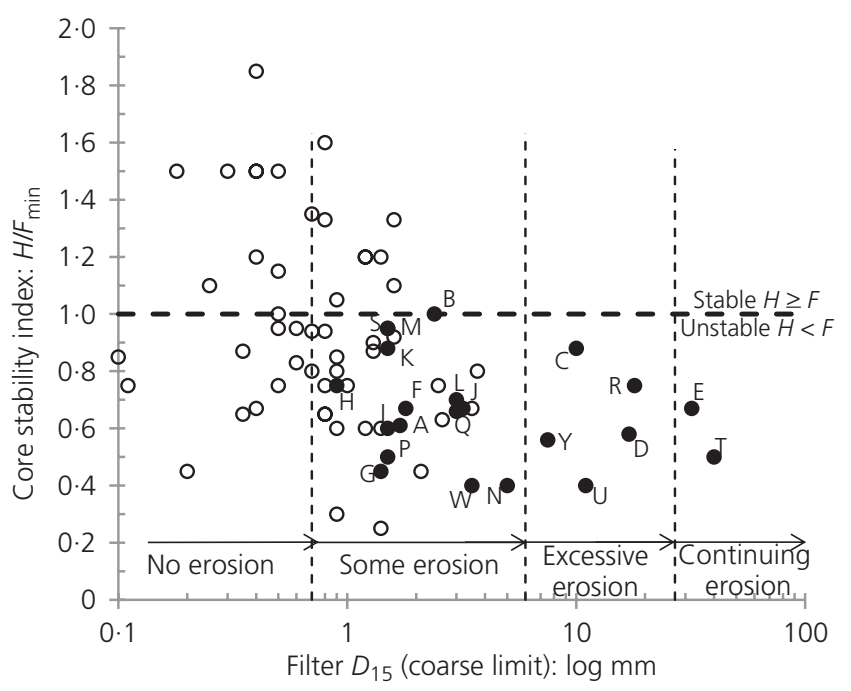

oDams with no observations to indicate internal erosion (2-3 dams)

- Dams with probable occurrence of internal erosion (1 dams)

Figure 8. Core stability index $\left(H / F_{\text {min }}\right)$ plotted against corresponding filter D15 (coarse limit) in relation to filter ranges as defined by Foster and Fell (2001). 74 dams in total including 22 category 1 dams (dam $\vee$ not included). The 'some erosion' range contains 44 dams ( 15 category 1 dams)

category 1 dams (Figure 9 and Table 2). Although a clear majority of dams that have experienced internal erosion are assessed as having unstable cores (93\%, 'no screening' data in Table 2), the Kenney-Lau method appears less suitable to soils with fines since dams evaluated as having unstable cores (77\%, Table 2) are not necessarily category 1 dams (the proportion is only $41 \%$, Table 2 'no screening' data).

Approach to data screening and its evaluation results To investigate whether the statistics improve within an optimum evaluation range, the initial data (unscreened in terms of fines and finer fraction) are compared to screened data. Figure 6 shows schematically how the fines and finer fraction are determined from the fine limit and coarse limit of the envelope, and the screening has been done with regards to the following aspects.

- Fines of $(i)$ fine limit (maximum fines), (ii) coarse limit (minimum fines) and (iii) average fines (mean of outer limits).

- Finer fraction of (iv) fine limit, (v) coarse limit and (vi) average finer fraction (mean of outer limits).

The diagnosis criteria in finding an optimum evaluation range are as follows.

- Is the evaluation more effective within the proposed evaluation range (i.e. up to the proposed boundary) in discerning dams with previous internal erosion (category 1 dams) from dams without (category 2-3 dams) compared to the unscreened core data?

- Is the evaluation less effective outside the proposed evaluation range (i.e. beyond the proposed boundary)?

Screening the cores according to (ii), (v) and (vi) was unsuccessful in discerning between category 1 dams and dams without internal erosion (category 2-3 dams). However, screening in terms of (iii) average fines and ( $i$ ) fine limit fines (max. fines) improved the correlation compared to unscreened data, and Table 2 presents the optimum evaluation ranges found, that is, $0-30 \%$ average fines and $0-45 \%$ fine limit fines (max. fines). There is also an improvement, although to a lesser degree, in terms of $0-35 \%$ finer fraction of the fine limit (max. fines) curve. These ranges have been identified from incrementally checking the application data and its dependence on the fines content (Figure 3) as well as the finer fraction (Figure 4). The average fines screening produces the most efficient discerning between category 1 dams and category $2-3$ dams, and it generated the following results.

- Dams evaluated as having unstable cores reduced to about $67 \%$ within the evaluation range $0-30 \%$ (Table 2 ) compared to about $77 \%$ with no screening and $83 \%$ outside the range (i.e. $31-47 \%$ ). The Li-Fannin adaptation reduces this further (Table 2).

- Dams without internal erosion (category 2-3 dams) with unstable cores reduced to about $44 \%$ compared to about $80 \%$ outside the range. The $\mathrm{Li}-\mathrm{Fannin}$ adaptation clearly reduces this amount to about $33 \%$ (Table 2).

- The proportion of dams with previous experience of internal erosion (category 1 dams) with regards to all dams with unstable cores increased to $60 \%$ (Table 2) compared to about $41 \%$ with no screening and $33 \%$ outside the range 


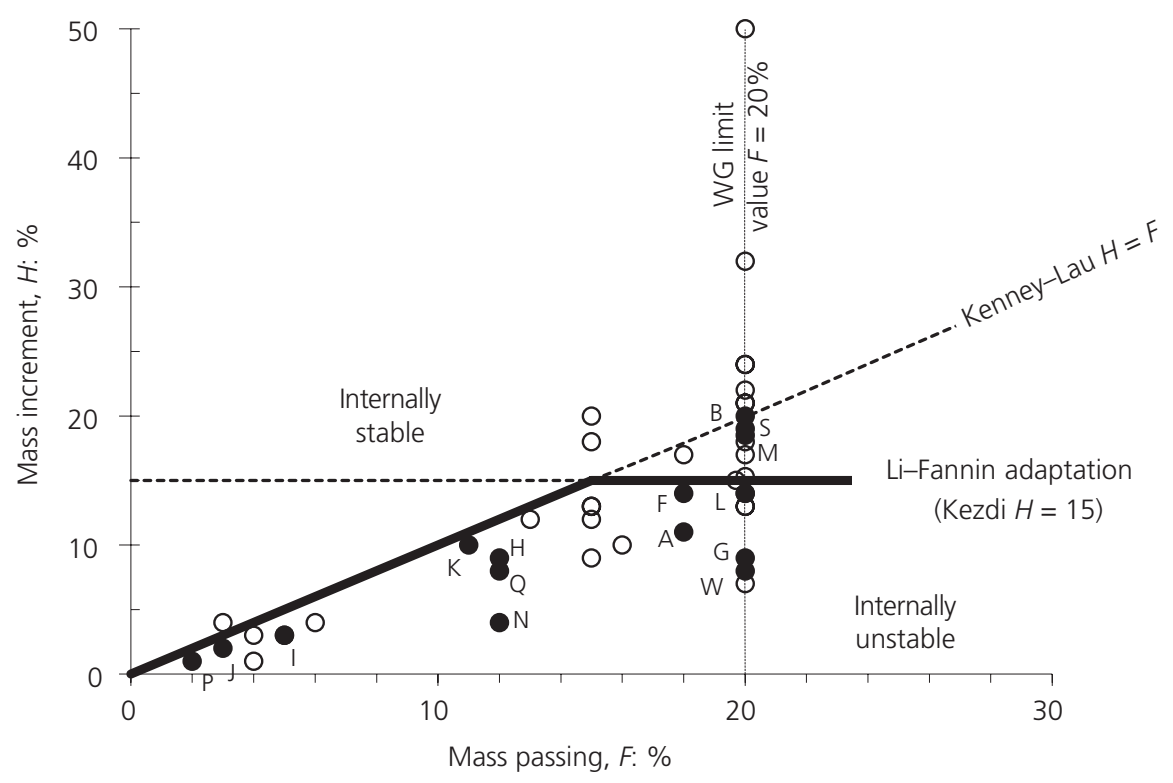

O Dams with no observations to indicate internal erosion (2-3 dams)

- Dams with probable occurrence of internal erosion (1 dams)

Figure 9. Dams with core soils against filters within the 'some erosion' filter range and unscreened results from application of the Kenney-Lau method and adaptation by Li-Fannin (44 dams in total including 15 category 1 dams)

\begin{tabular}{|c|c|c|c|c|c|c|c|}
\hline & $\begin{array}{l}\text { \% Internally } \\
\text { unstable wrt } \\
\text { all dams }\end{array}$ & $\begin{array}{l}\text { \% Internally } \\
\text { unstable wrt } \\
\text { all category } \\
\text { 2-3 dams }\end{array}$ & $\begin{array}{c}\% \text { Internally } \\
\text { unstable wrt } \\
\text { all category } \\
1 \text { dams }\end{array}$ & $\begin{array}{l}\text { \% Proportion } \\
\text { of category } 1 \\
\text { dams wrt all } \\
\text { unstable dams }\end{array}$ & $\begin{array}{l}\% \text { Proportion } \\
\text { of category } 1 \\
\text { dams wrt all } \\
\text { stable dams }\end{array}$ & $\begin{array}{l}\text { Number } \\
\text { of dams }\end{array}$ & Cat. 1/cat. 2-3 \\
\hline No screening & $77 \cdot 3(63 \cdot 6)$ & $69 \cdot 0(55 \cdot 2)$ & $93 \cdot 3(80 \cdot 0)$ & $41 \cdot 2(42 \cdot 9)$ & $10 \cdot 0(18 \cdot 8)$ & 44 & $15 / 29$ \\
\hline $\begin{array}{l}\text { Fines fine limit } \\
\text { (max. fines) } 0-45 \%\end{array}$ & $78 \cdot 3(65 \cdot 2)$ & $61 \cdot 5(53 \cdot 8)$ & $100(80 \cdot 0)$ & $55 \cdot 6(53 \cdot 3)$ & $0(25 \cdot 0)$ & 23 & $10 / 13$ \\
\hline $\begin{array}{l}\text { Fines fine limit } \\
\text { (max. fines) 46-65\% }\end{array}$ & $76 \cdot 2(61 \cdot 9)$ & $75 \cdot 0(56 \cdot 3)$ & $80 \cdot 0(80 \cdot 0)$ & $25 \cdot 0(30 \cdot 8)$ & $20 \cdot 0(12 \cdot 5)$ & 21 & $5 / 16$ \\
\hline Fines average $0-30 \%$ & $66 \cdot 7(53 \cdot 3)$ & $44 \cdot 4(33 \cdot 3)$ & $100(83 \cdot 3)$ & $60 \cdot 0(62 \cdot 5)$ & $0(14 \cdot 3)$ & 15 & $6 / 9$ \\
\hline $\begin{array}{l}\text { Fines average } \\
31-47 \%\end{array}$ & $82 \cdot 8(69 \cdot 0)$ & $80 \cdot 0(65 \cdot 0)$ & $88.9(77 \cdot 8)$ & $33 \cdot 3(35 \cdot 0)$ & $20 \cdot 0(22 \cdot 2)$ & 29 & $9 / 20$ \\
\hline $\begin{array}{l}\text { Finer fraction of fine } \\
\text { limit (max. fines) } \\
\text { 0-35\% }\end{array}$ & $76 \cdot 0(64 \cdot 0)$ & $66 \cdot 7(53 \cdot 3)$ & $90 \cdot 0(80 \cdot 0)$ & $47 \cdot 4(50 \cdot 0)$ & $16 \cdot 7(22 \cdot 2)$ & 25 & $10 / 15$ \\
\hline $\begin{array}{l}\text { Finer fraction of fine } \\
\text { limit (max. fines) } \\
36-52 \%\end{array}$ & $78.9(63 \cdot 2)$ & $71 \cdot 4(57 \cdot 1)$ & $100(80 \cdot 0)$ & $33 \cdot 3(33 \cdot 3)$ & $0(14 \cdot 3)$ & 19 & $5 / 14$ \\
\hline $\begin{array}{l}\text { Table 2. Compilation of } \\
\text { to screened fines and fir } \\
\text { the 'some erosion' filter } \\
\text { without regrading (Li-Fa }\end{array}$ & $\begin{array}{l}\text { Kenney-Lau ap } \\
\text { er fraction data } \\
\text { ange. Based on } \\
\text { nin results in b }\end{array}$ & $\begin{array}{l}\text { lication results a } \\
\text { with regards to o } \\
\text { original grain siz } \\
\text { ackets) }\end{array}$ & $\begin{array}{l}\text { ccording } \\
\text { lams in } \\
\text { e curves }\end{array}$ & & & & \\
\hline
\end{tabular}




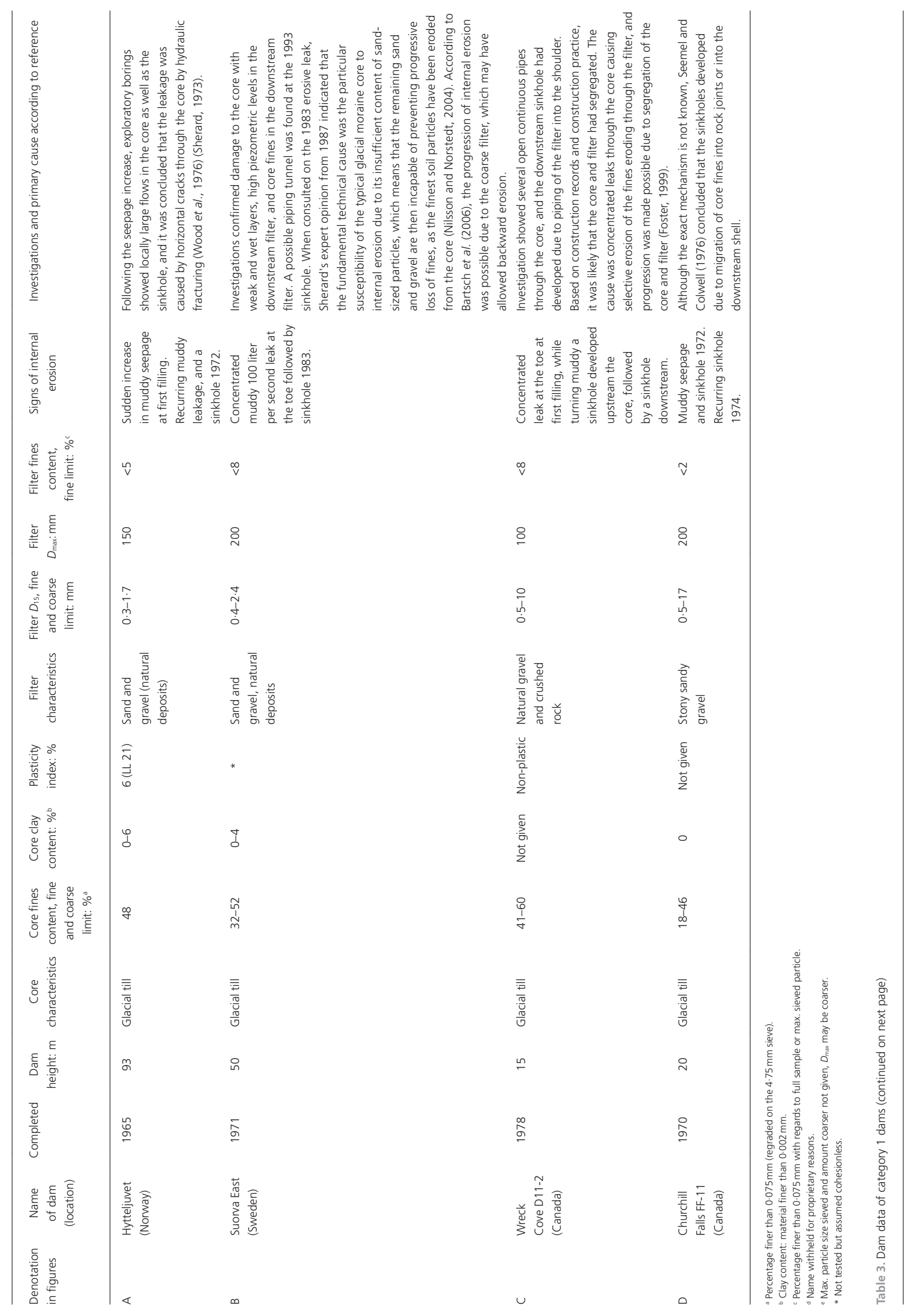




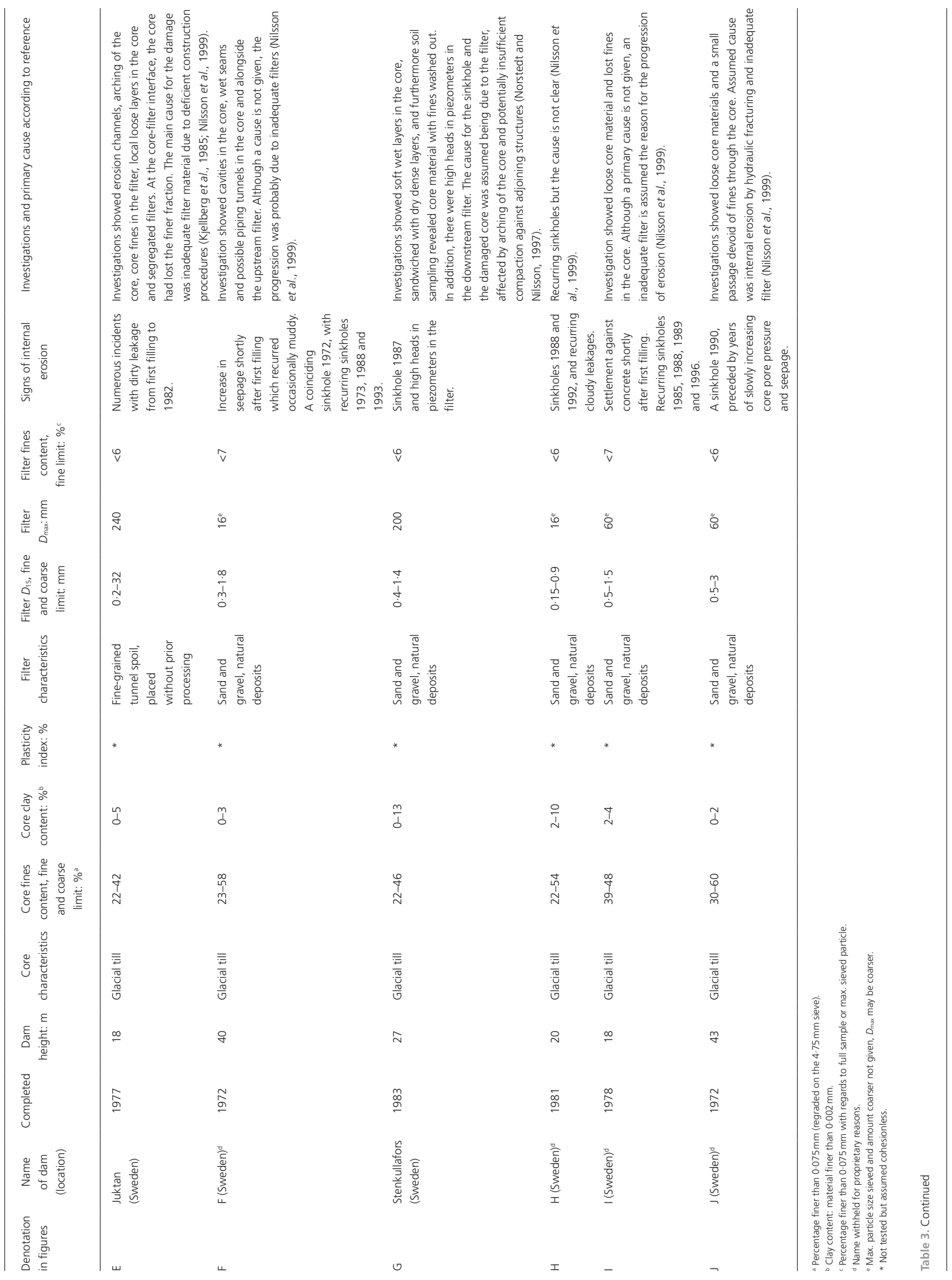




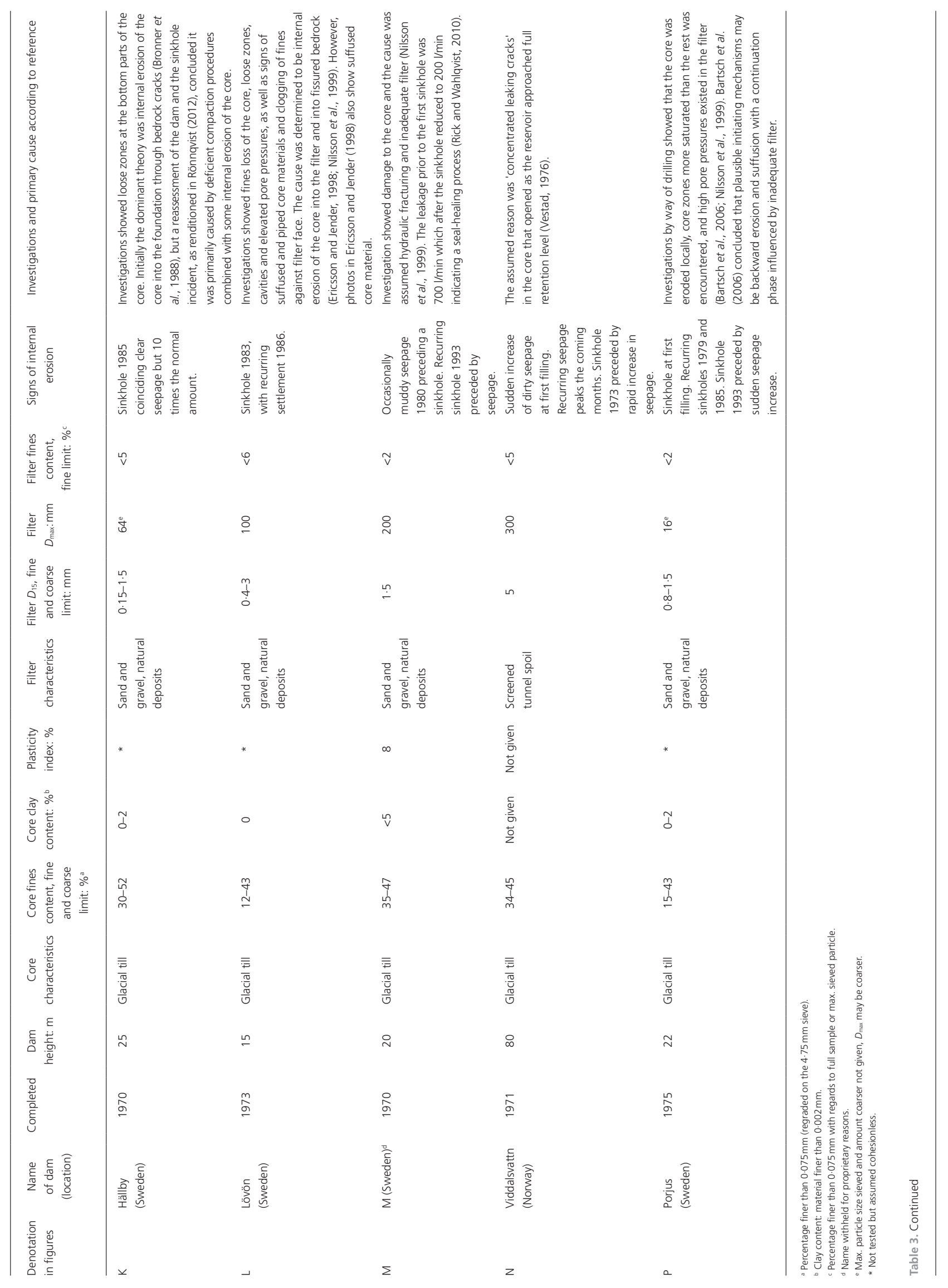




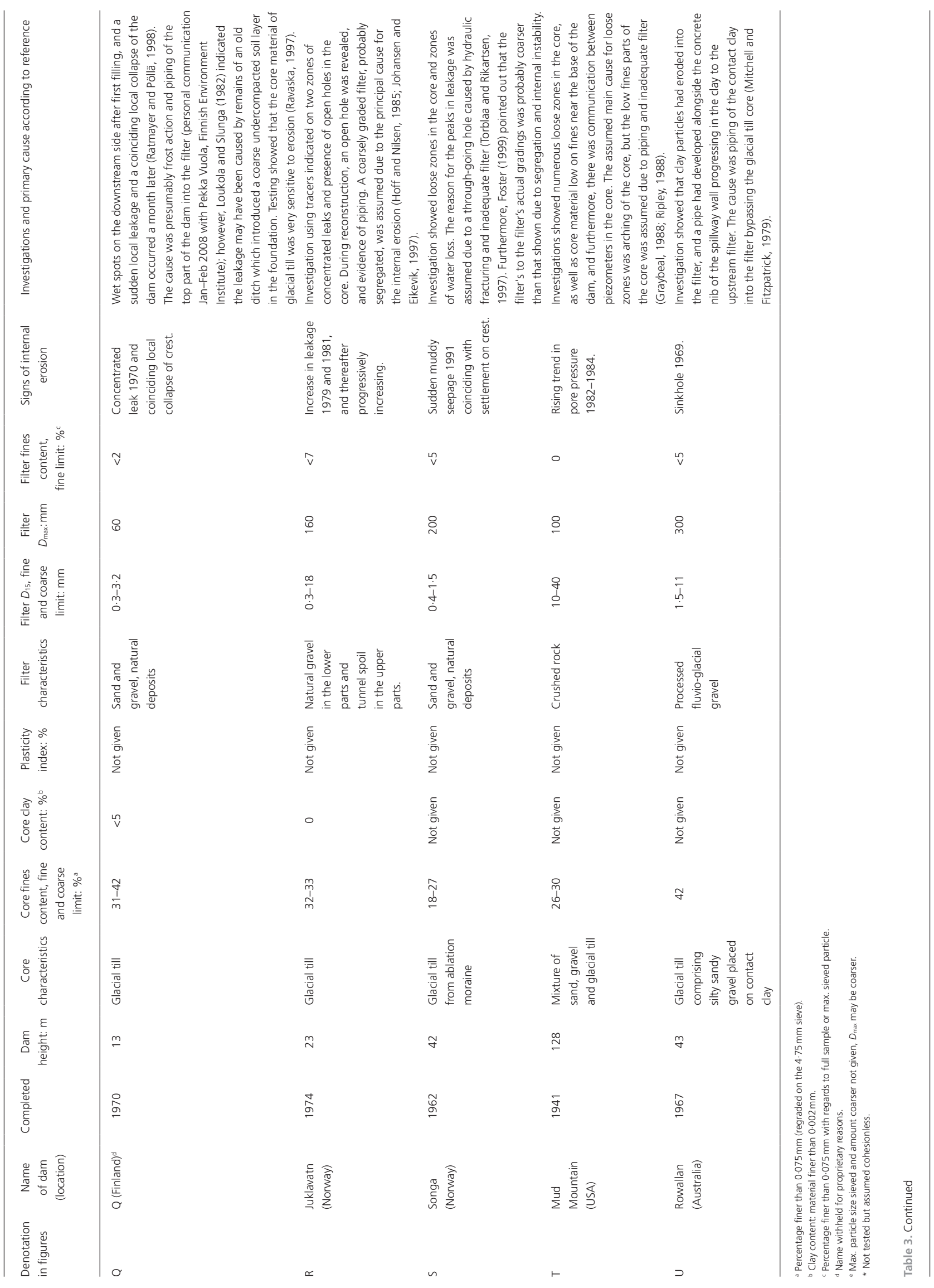




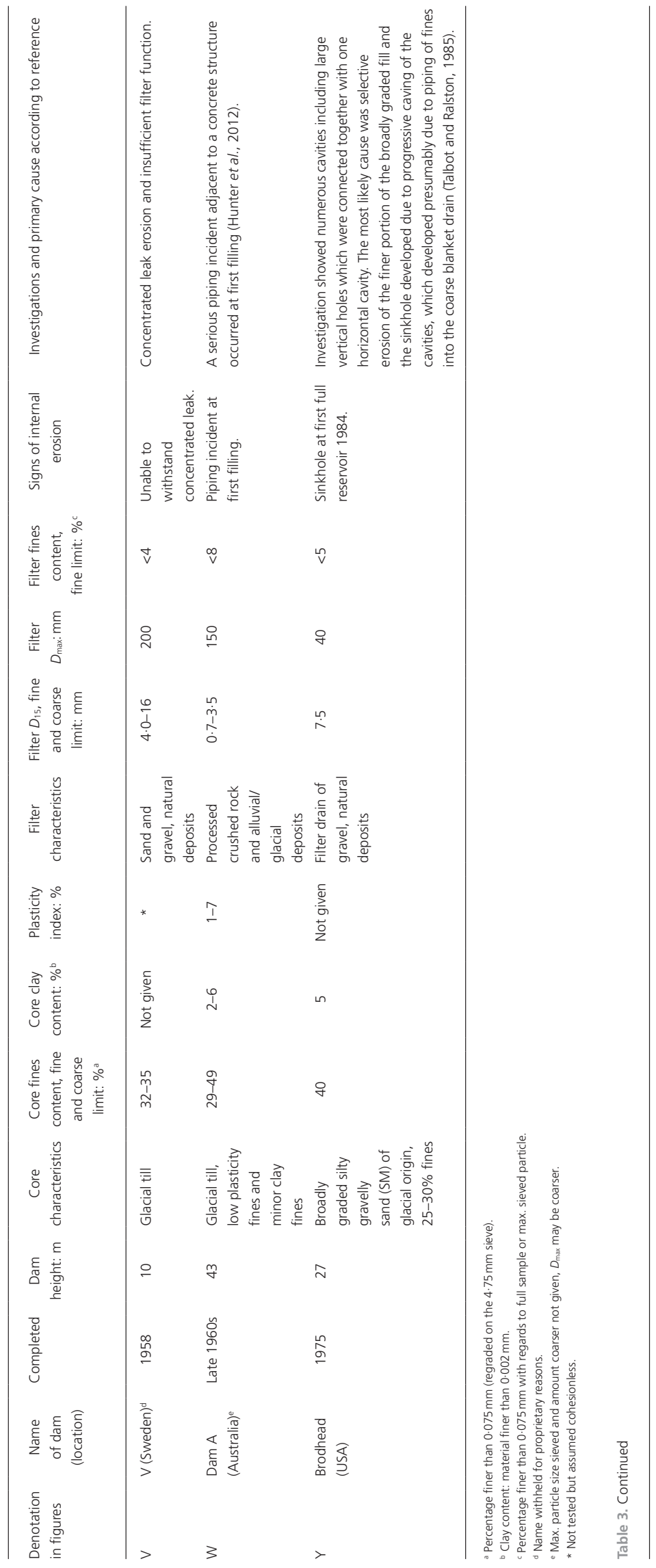




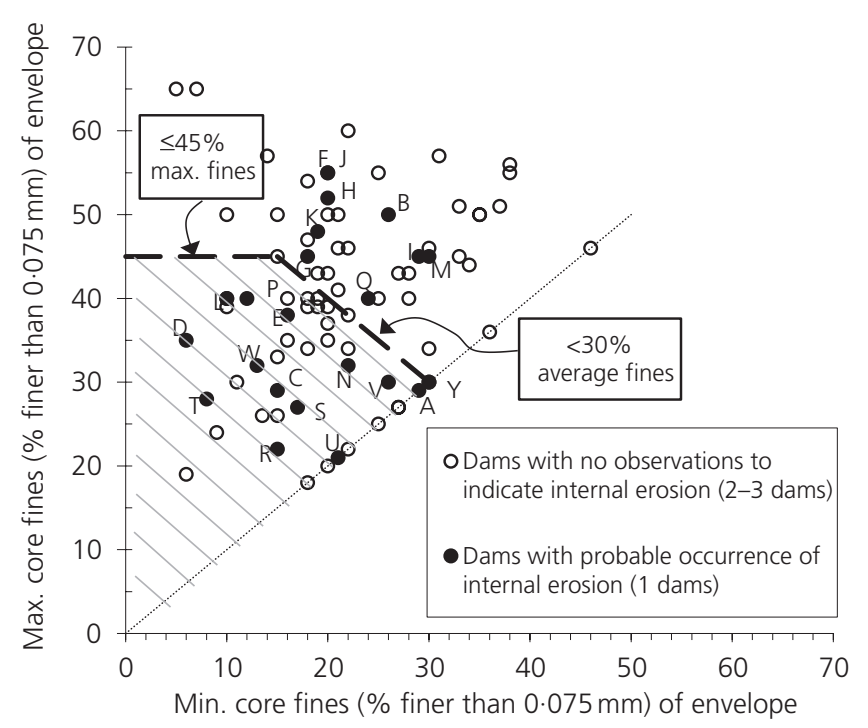

Figure 10. Proposed evaluation ranges when using the KenneyLau method on glacial till core soils (less than 0\%-30\% average fines and less than $45 \%$ max. fines) superimposed on the full set of dams (84 dams including 23 category 1 dams)

(i.e. $31-47 \%$ ). The Li-Fannin adaptation increases this proportion to about $63 \%$ (Table 2 ).

With regards to the 44 dams within the 'some erosion' range (Figure 8) as defined by Foster and Fell (2001), the evaluation range of $0 \%-30 \%$ average fines is obviously strict since it includes only 15 dam cores (Table 2 ) of which six category 1 dams (dams A, $\mathrm{L}, \mathrm{N}, \mathrm{P}, \mathrm{S}$ and $\mathrm{W}$, as described in Table 3). The rest (29 dams) are outside the range and thus potentially outside the method's scope. Within this range, nevertheless, the correlation between the core soils' stability index $\left(H / F_{\min }\right)$ and category 1 dams improves, which suggests a link between Kenney-Lau application data and dams that have experienced internal erosion incidents. This indicates that the Kenney-Lau method has merit on glacial till core soils with some fines.

\section{Conclusions}

Based on the evaluation of grain size curves from core construction data of a large number of existing dams with glacial till cores and contrasting dams with performance history of internal erosion (herein called category $1 \mathrm{dams}$ ) against dams without signs of internal erosion (herein called category 2-3 dams), it appears that the Kenney and Lau $(1985,1986)$ method can be extended with caution to include glacial till cores soils. This provides, however, the core soil having a finer fraction less than $35 \%$ and within the proposed evaluation ranges: ( $i$ ) average fines (of the outer limits of the envelope) less than $30 \%$, and (ii) fine limit fines (max. fines of envelope) less than $45 \%$. Figure 10 shows the proposed evaluation limits superimposed over the fines plot for the full set of dams.
Furthermore, the Li-Fannin adaptation generally provides a less conservative evaluation than that of Kenney-Lau based on the dams in this study. The comparative analysis has been done on dams within the same filter range as an attempt to minimise the influence of the filter coarseness, thus elevating the influence of the core.

Further work is necessary to fully understand the internal instability and suffusion susceptibility of cohesionless glacial tills. Nevertheless, recognising that internal erosion incidents with sinkholes in dams are likely the result of, not one single mechanism, but interplaying processes (e.g. suffusion, backward erosion), herein, encouraging results arise between a core's internal instability and the historic performance data of dams, which suggests that the internal instability of the core soil may co-influence the internal erosion process.

\section{Acknowledgements}

Thanks are due to Prof. Jonathan Fannin of the University of British Columbia for valuable discussion.

The research presented was carried out as part of the 'Swedish Hydropower Centre - SVC'. SVC has been established by the Swedish Energy Agency, Elforsk and Svenska Kraftnät together with Luleå University of Technology, the Royal Institute of Technology, Chalmers University of Technology and Uppsala University.

\section{REFERENCES}

Bartsch M, Bono N, Nilsson Å and Norstedt U (2006) Alternative measures to improve the resistance against internal erosion upgrading of the Suorva and the Porjus rockfill dams.

Proceedings of the ICOLD 22nd Congress, Barcelona, Spain, Q.86, pp. 207-228.

Bronner N, Fagerström H and Stille H (1988) Bedrock cracks as a possible cause of leakage in two Swedish dams. Proceedings of the 16th ICOLD Congress, San Francisco, CA, USA, Q61 R55, pp. 1029-1051.

Ericsson J and Jender M (1998) Documentation and investigation of damages in Lövön dam. Master's thesis, Luleå University of Technology, Luleå, Sweden.

Foster MA (1999) The Probability of Failure of Embankment Dams by Internal Erosion and Piping. PhD thesis, The University of New South Wales, Kensington, NSW, Australia.

Foster M, Fell R and Spannagle M (2000) The statistics of embankment dam failures and accidents. Canadian Geotechnical Journal 37(5): 1000-1024.

Foster MA and Fell R (2001) Assessing embankment dam filters that do not satisfy design criteria. Journal of Geotechnical and Geoenvironmental Engineering 127(4): 398-407.

Graybeal KD (1988) Seepage control at Mud Mountain dam. Proceedings of the ICOLD 16th Congress, San Francisco, CA, USA, Q.61, pp. 539-555.

Hoff T and Nilsen K (1985) Erosion and leakage problems on some Norwegian dams. Proceedings of the ICOLD 15th Congress, Lausanne, Switzerland, Q59, pp. 573-586. 
Hunter G, Fell R and Topham C (2012) Backward erosion piping: what are the chances of that? Proceedings of Ancold 2012, Australian National Committee on Large Dams, Perth, WA, Australia.

ICOLD (International Commission on Large Dams) (2013) Bulletin 164: Internal Erosion of Existing Dams, Levees and Dikes, and their Foundations. Volume 1: Internal Erosion Processes and Engineering Assessment (Bridle R and Fell R (eds)). ICOLD, Lausanne, Switzerland.

Johansen PM and Eikevik JH (1997) Internal erosion and rehabilitation of Jukla rockfill dams. Proceedings of the ICOLD 19th Congress, Florence, Italy, Q.73, pp. 245-253.

Kenney TC and Lau D (1985) Internal stability of granular filters. Canadian Geotechnical Journal 22(2): 215-225.

Kenney TC and Lau D (1986) Internal stability of granular filters: reply. Canadian Geotechnical Journal 23(3): 420-423.

Kezdi A (1979) Soil Physics - Selected Topics. Elsevier, Amsterdam, the Netherlands.

Kjellberg R, Norstedt U and Fagerström H (1985) Leakage in and reconstruction of the Juktan earth and rock fill dams. Proceedings of the 15th ICOLD Congress, Lausanne, Switzerland, Q59, R35, pp. 553-573.

Lafleur J and Nguyen PH (2007) Internal stability of particles in dam cores made of cohesionless broadly graded moraines. In Internal Erosion of Dams and their Foundations (Fell R and Fry JJ (eds)). Taylor and Francis, Balkema, London, UK, pp. 151-158.

Li M and Fannin RJ (2008) Comparison of two criteria for internal stability of granular soil. Canadian Geotechnical Journal 45(9): 1303-1309.

Lilja HM, Rother M and Ravaska OT (1998) Filter material study for an earth dam project. In Dam Safety (Berga L (ed.)). Balkema, Rotterdam, the Netherlands, pp. 825-832.

Loukola E and Slunga E (1982) Observation on the seepage through and under dams made of glacial till. Proceedings of the 14th ICOLD Congress, Rio de Janeiro, Brazil, Q.52, pp. 293-304.

Mitchell WR and Fitzpatrick MD (1979) An incident in Rowallan Dam. Proceedings of the 13th ICOLD Congress, India, Q.49, pp. 195-210.

Moffat R, Fannin RJ and Garner S (2011) Spatial and temporal progression of internal erosion in cohesionless soil. Canadian Geotechnical Journal 48(3): 399-412.

Moffat R and Fannin RJ (2011) A hydromechanical relation governing internal stability of cohesionless soil. Canadian Geotechnical Journal 48(3): 413-424.

Nilsson Å, Ekström I and Söder C (1999) Sinkholes in Swedish embankment dams. Elforsk Report 99: 34.

Nilsson Å and Norstedt U (2004) Reverse filters on the downstream slope to compensate for coarse graded filters in Swedish dams. Proceedings of CDA2004, Canadian Dam Association, Ottawa, Canada.

Norstedt U and Nilsson $\AA$ (1997) Internal erosion and ageing in some of the Swedish earth and rockfill dams. Proceedings of the 19th ICOLD Congress, Florence, Italy, vol. II, pp. 307-319.

Rathmayer H and Pöllä J (1998) Finnish dam safety code prohibited collapse of the Uljua earth dam. In Dam Safety (Berga L (ed.)). Balkema, Rotterdam, the Netherlands, pp. 903-910.

Ravaska O (1997) Piping susceptibility of glacial till. Proceedings of the 19th ICOLD Congress, Florence, Italy, Q73, pp. 455-471.

Rick A and Wahlqvist P (2010) Safety Analysis of Existing Embankment Dams - a Case Study of Rengård Power Station. Lund University, Lund, Sweden, report no. 5352.

Ripley CF (1988) Comments on Q.61-R.29 and R.55. Proceedings of the 16th ICOLD Congress, San Francisco, CA, USA, vol. V.

Rönnqvist H (2009) Long-term behaviour of internal erosion afflicted dams comprising broadly graded soils. Dam Engineering 20(2): 149-197.

Rönnqvist H (2010) Predicting Surfacing Internal Erosion in Moraine Core Dams. KTH TRITA-LWR licentiate thesis, Royal Institute of Technology, Stockholm, Sweden.

Rönnqvist H (2012) Applying available internal erosion criteria to dams with cores of glacial till - a reassessment of a 1980s sinkhole. In Dams: Engineering in a Social and Environmental Context (Pepper A (ed.)). ICE Publishing, London, UK, pp. 131-144.

Seeme IRN and Colwell CN (1976) Drainage provisions and leakage investigations of the Churhills falls dams and dykes. Proceedings of the 12th ICOLD Congress, Mexico, pp. 107-127.

Sherard JL (1973) Embankment dam cracking. In Embankmentdam Engineering (Casagrande volume) (Hirschfeld RC and Poulos SJ (eds)). Wiley, New York, NY, USA, pp. 324-328.

Sherard JL (1979) Sinkholes in dams of coarse, broadly graded soils. Proceedings of the 13th ICOLD Congress, India, vol. II, pp. 25-35.

Sherard JL and Dunnigan LP (1989) Critical filters for impervious soils. Journal of Geotechnical Engineering, ASCE 115(7): 927-947.

Skempton AW and Brogan JM (1994) Experiments on piping in sandy gravels. Géotechnique 44(3): 449-460.

Talbot JR and Ralston D (1985) Earth dam seepage control - SCS experience. In Proceedings of a Symposium of Seepage and Leakage from Dams and Impoundments (Volpe R and Kelly W (eds)). American Society of Civil Engineers, New York, NY, USA, pp. 44-65.

Torblaa I and Rikartsen C (1997) Songa, sudden variations of the leakage in a 35 years old rockfill dam. Proceedings of the 19th ICOLD Congress, Florence, Italy, Q.73, pp. 255-267.

Vestad H (1976) Viddalsvatn dam a history of leakages and investigations. Proceedings of the 12th ICOLD Congress, Mexico, Q45, R22, pp. 369-390.

Wan CF (2005) Experimental Investigations of Piping Erosion and Suffusion of Soils in Embankment Dams and Their Foundations. PhD thesis, The University of New South Wales, Kensington, NSW, Australia. 
Wan CF and Fell R (2004) Experimental Investigation of Internal Instability of Soils in Embankment Dams and their Foundation. The University of New South Wales, Kensington, NSW, Australia, UNICIV report no. 429.

Wan CF and Fell R (2007) Investigation of internal erosion by the process of suffusion in embankment dams and their foundations. In Internal Erosion of Dams and their Foundations (Fell R and Fry JJ (eds)). Taylor and Francis, Balkema, London, UK, pp. 219-234.

Wood D, Kjaernsli B and Höeg K (1976) Thoughts concerning the unusual behavior of Hyttejuvet dam. Proceedings of the ICOLD 12th Congress, Mexico, Q.45, pp. 391-414.

\section{WHAT DO YOU THINK?}

To discuss this paper, please submit up to 500 words to the editor at journals@ice.org.uk. Your contribution will be forwarded to the author(s) for a reply and, if considered appropriate by the editorial panel, will be published as a discussion in a future issue of the journal. 